\title{
Pengaruh pemberian jus buah naga merah setelah latihan fisik intensitas berat terhadap jumlah leukosit
}

\author{
Alginda Pranata Tarigan, Novita Sari Harahap *, Deni Rahman Marpaung \\ Program Studi Ilmu Keolahragaan, Fakultas Ilmu Keolahragaan, Universitas Negeri Medan. \\ Jalan Willem Iskandar Pasar V, Medan, Sumatera Utara 20221, Indonesia. \\ * Corresponding Author. Email: novitahrp74@gmail.com
}

Received: 17 May 2020; Revised: 24 July 2020; Accepted: 3 August 2020

\begin{abstract}
Abstrak: Penelitian ini bertujuan untuk mengetahui pengaruh pemberian jus buah naga merah setelah melakukan latihan fisik intensitas berat terhadap jumlah leukosit. Metode penelitian ini adalah pre-experimental dengan desain pretest and posttest group design. Populasi penelitian adalah mahasiswa Ilmu Keolahragaan angkatan 2018, Universitas Negeri Medan dengan purposive sampling diperoleh sampel 10 orang. Sampel dibagi atas 2 kelompok yaitu kelompok P1; kelompok yang diberi latihan fisik intensitas berat tanpa diberi jus buah naga merah dan kelompok P2; kelompok yang diberi latihan fisik intensitas berat dan diberi jus buah naga merah. Penelitian ini dilakukan pada Januari 2020 sampai dengan Februari 2020, dosis buah naga merah $2,8 \mathrm{~g} / \mathrm{kgBB}$ diberikan setiap hari selama 21 hari. Analisis data yang digunakan adalah Paired T-Test dan Independent T-Test. Hasil penelitian pada kelompok P1 $(\mathrm{p}=0,009)$ dan kelompok P2 ( $\mathrm{p}=0,021)$ samasama terdapat peningkatan jumlah leukosit setelah latihan fisik intensitas berat. Analisa selanjutnya bahwa terdapat peningkatan jumlah leukosit lebih rendah pada kelompok yang diberi jus buah naga merah setelah latihan fisik berat (P2) dibandingkan kelompok yang tidak diberi jus buah naga merah ( $\mathrm{P} 1$ ) dengan $\mathrm{p}=0,025$. Kesimpulan penelitian ini menunjukkan bahwa pemberian jus buah naga merah dapat mengurangi peningkatan jumlah leukosit setelah melakukan latihan fisik intensitas berat.
\end{abstract}

Kata Kunci: buah naga merah, latihan fisik, leukosit.

\section{Effect of giving red dragon fruit juice after severe intensity exercise against leukocyte amounts}

\begin{abstract}
The purpose of this study was to determine the effect of giving red dragon fruit juice after severe exercise on the number of leukocytes. This research method was a pre-experimental design with two groups pretest and posttest group design. The study population was students of Sports Science 2018, with a purposive sampling sample of 10 people. The sample was divided into 2 groups: group P1; the group that was given heavy intensity physical exercise without being given red dragon fruit juice and the P2 group; the group that was given heavy intensity physical exercise and was given red dragon fruit juice. This research was conducted from January 2020 until February 2020, the dose of red dragon fruit is $2.8 \mathrm{~g} / \mathrm{kg} \mathrm{BW}$ given daily for 21 days. The data analysis technique used was Paired t-test and Independent t-test. The results of the study in group P1 and group P2 were both an increase in the number of leukocytes after physical exercise heavy intensity with $p$-value $=0.009$ and $p$-value $=0.021$. Further analysis that there was a decrease in the number of leukocytes in the group given red dragon fruit juice after strenuous physical exercise (P2) compared to the group that did not get red dragon fruit juice $(P 1)$ with $p$-value $=0.025$. The conclusion of this study shows that administration of red dragon fruit juice can reduce the increase in the number of leukocytes after doing heavy intensity physical exercise.
\end{abstract}

Keywords:leukocytes, red dragon fruit, severe ntensity exercise

How to Cite: Tarigan, A., Harahap, N., \& Marpaung, D. (2020). Pengaruh pemberian jus buah naga merah setelah latihan fisik intensitas berat terhadap jumlah leukosit. Jurnal Keolahragaan, 8(2), 140-147. doi:https://doi.org/10.21831/jk.v8i2.31838

\section{PENDAHULUAN}

Olahraga dapat meningkatkan imunitas tubuh seperti latihan aerobik selama 30 menit dapat mengaktifkan fungsi leukosit sebagai komponen utama kekebalan tubuh. Akan tetapi jika latihan fisik 
dilakukan dengan intensitas berat dapat menurunkan kekebalan tubuh. Latihan fisik berat berpotensi menghasilkan radikal bebas yang mengakibatkan kerusakan pada sel (Dékány et al., 2008).

Olahraga merupakan salah satu faktor stres yang dapat menyebabkan perubahan seluler secara fisiologi terhadap fungsi sistem hematologi seperti perubahan jumlah leukosit. Perubahan jumlah leukosit ini bergantung pada frekuensi latihan, intensitas latihan, jenis latihan, dan durasi latihan (Bhatti \& Shaikh, 2007; Hazar \& Y1lmaz, 2008). Sistem hematologi terdiri atas darah dan tempat darah dihasilkan. Darah terbagi atas sel-sel darah yaitu, eritrosit (sel darah merah), leukosit (sel darah putih), dan trombosit (keping darah) (Ganong, 2010). Olahraga dengan metode latihan metode High Intensity Interval Training dapat meningkatkan $\mathrm{VO}_{2}$ max namun tidak meningkatkan nilai hemoglobin, eritrosit dan hematokrit (Putra et al., 2017).

Leukosit memiliki fungsi sebagai sistem pertahanan tubuh dengan cara diangkut menuju sel-sel yang mengalami inflamasi seperti akibat stress oksidatif (Guyton \& Hall, 2006; Sherwood, 2015). Jumlah leukosit dipengaruhi oleh stimulasi terhadap kelenjar adrenal. Stimulus ini dapat terjadi secara farmakologis dan karena adanya kebutuhan fisiologis. Stimulasi fisiologis yang dapat mengakibatkan peningkatan jumlah leukosit yaitu olahraga, emosi, adanya suhu yang ekstrim, (Natale et al., 2003).

Dalam keadaan fisiologis, saat terjadi metabolisme dalam tubuh maka sel-sel tubuh secara rutin dapat menghasilkan radikal bebas-radikal bebas (Marius-Daniel et al., 2010). Produksi radikal bebas di dalam tubuh dapat di eliminasi oleh sistem pertahanan antioksidan endogen seperti glutathione peroxidase (GPx) dan catalase (CAT). Selain itu ada juga antioksidan eksogen dari diet atau makanan yang dapat menetralkan radikal bebas seperti vitamin E, C dan flavonoid (Rao et al., 2011). Ketika jumlah radikal bebas atau oksidan lebih banyak dari kemampuan sistem pertahanan antioksidan seluler atau kemampuan sistem pertahanan tubuh seluler tidak seimbang dengan jumlah radikal bebas maka akan terjadi stress oksidatif yang dapat merusak membrane sel (Kawamura \& Muraoka, 2018). Stres oksidatif ini merupakan proses fisiologis yang dapat menyebabkan gangguan kekebalan tubuh (Gleeson \& Robson-Ansley, 2006; Mastorakos et al., 2005) sehingga dapat menurunkan derajat kesehatan. Hasil study terdahulu oleh (Patlar, 2010) menyatakan bahwa terjadi peningkatan jumlah leukosit setelah latihan fisik selama 4 minggu dengan intensitas submaksimal. Hasil penelitian oleh (Valizadeh et al., 2011) juga menyatakan bahwa terjadi peningkatan setelah berlari pada treadmill selama 30 menit dengan intensitas $85 \%$ dari VO2max dan dengan intensitas 60\% VO2max selama 90 menit.

Saat olahraga konsumsi oksigen seluruh tubuh dapat meningkat 10 sampai 20 kali dibandingkan istirahat sehingga meningkatkan metabolisme energi melalui fosforilasi. sedangkan jumlah antioksidan seluler dalam tubuh jumlahnya terbatas (Alessio, et al. 2000). Pada saat latihan fisik maksimal kebutuhan oksigen pada sel-sel otot dapat meningkat sampai 100 kali lipat (Urso \& Clarkson, 2003; Yavari et al., 2015). Latihan fisik intensitas berat potensial untuk menimbulkan stress oksidatif yaitu adanya ketidakseimbangan antara radikal bebas dengan kapasitas pertahanan antioksidan. Stres oksidatif terjadi dimana ntioksidan tidak dapat mengikat radikal bebas yang dihasilkan selama latihan fisik intensitas berat. Stres oksidatif ini dapat menyebabkan kerusakan pada enzim, reseptor protein, membran lipid, dan DNA yang disebut dengan kerusakan oksidatif (Marciniak et al., 2009). Kerusakan oksidatif akibat latihan fisik dapat dicegah dengan dengan meningkatkan kandungan antioksidan makanan (Gomez-Cabrera et al., 2008). Oleh karena itu tubuh harus mempunyai pertahanan antioksidan yang optimal untuk melindungi serangan dari radikal bebas. Banyak atlet percaya bahwa dengan mengkonsumsi antioksidan dapat mengurangi kerusakan otot, meningkatkan immunitas dan kelelahan sehingga akan meningkatkan performa (Braakhuis \& Hopkins, 2015).

Buah naga merah (Hylocereus polyrhizus) adalah buah yang cukup unik dan akhir-akhir ini banyak digemari dan dibudidayakan masyarakat khususnya di Indonesia. Diyakini buah naga merah mempunyai potensi sebagai antioksidan alami. Beberapa penelitian invitro telah menunjukkan bahwa ekstrak buah naga merah mempunyai kemampuan sebagai antioksidan (Arifin et al., 2012; Minh, 2014; Stintzing et al., 2002). Penelitian sebelumnya yang dilakukan oleh (Khotimah et al., 2018) menyatakan bahwa pemberian jus buah naga merah pada lansia yang melakukan senam lansia dapat meningkatkan kadar High Density Lipoprotein (HDL). Potensi buah naga merah sebagai antioksidan yang dapat menetralkan radikal bebas dalam sistem biologis, karena mengandung senyawa flavonoid dan polifenol, (Mahattanatawee et al., 2006).

Berdasarkan uraian pada paragraf sebelumnya maka penelitian ini bertujuan untuk mengetahui pengaruh pemberian jus buah naga merah setelah melakukan latihan intensitas berat terhadap jumlah leukosit. 


\section{METODE}

Metode penelitian ini menggunakan metode pre-experimental dengan desain two group pretest and posttest group design. Penelitian ini dilakukan di Laboratorium Fisik Fakultas Ilmu Keolahragaan Universitas Negeri Medan dan Laboratorium Kesehatan Daerah Provinsi Sumatera Utara.

Populasi adalah mahasiswa Ilmu Keolahragaan angkatan 2018. Teknik pengambilan sampel dengan purposive sampling, yaitu berdasarkan kriteria inklusi sebagai berikut: sehat, laki-laki, tidak melakukan latihan fisik sebelum melakukan penelitian, bukan atlet, tidak perokok dan tidak mengkonsumsi suplemen dan antioksidan dua minggu sebelum dan selama penelitian, serta bersedia mengikuti prosedur selama penelitian. Selain itu kriteria eksklusi adalah tidak bersedia menandatangani inform concent. Sampel penelitian yang memenuhi kriteria didapat sebanyak 10 orang, kemudian dibagi menjadi dua kelompok secara acak, masing-masing terdiri dari lima orang mahasiswa, yaitu kelompok P1 (kontrol): kelompok yang diberi latihan fisik intensitas berat dan untuk penelitian yang selanjutnya; kelompok P2; kelompok yang diberi latihan fisik intensitas berat dan diberi jus buah naga merah.

Sebelum penelitian dimulai, diberikan penjelasan kepada calon subjek penelitian mengenai maksud dan tujuan penelitian, serta sampel yang bersedia ikut dalam penelitian menandatangani informed concent atau lembar persetujuan. Selama penelitian, subjek dianjurkan supaya cukup istirahat, menghindari suhu yang ekstrim yang dapat menyebabkan leukosit meningkat.

Sebelum dimulai latihan treadmill dilakukan pengambilan darah vena oleh analis kesehatan untuk pemeriksaan jumlah leukosit. Latihan fisik intensitas berat berupa latihan treadmill dengan intensitas 80-85\% DNM (denyut nadi maksimal), frekuensi 3 x seminggu selama 21 hari. Pemberian Jus buah naga merah sebelum latihan dengan dosis $2,8 \mathrm{~g} / \mathrm{kbBB} / \mathrm{hari}$ dihaluskan dengan menggunakan blender kemudian ditambahkan $70 \mathrm{ml}$ air, diberikan 1 x sehari selama 21 hari (Khotimah et al., 2018). Penelitian oleh (Khotimah et al., 2018) menggunakan dosis yang sama dan diberikan selama 14 hari, perbedaannya adalah waktu pemberian jus buah naga merah pada penelitian ini lebih lama yaitu selama 21 hari. Segera setelah latihan treadmill pada akhir waktu penelitian kembali dilakukan pengambilan darah vena oleh analis kesehatan untuk pemeriksaan jumlah leukosit. Pemeriksaan jumlah leukosit dilakukan di Laboratorium Kesehatan daerah Provinsi Sumatera Utara, menggunakan alat Analyzer Hematolog.

Data yang didapat terlebih dulu ditentukan distribusi dan homogenitasnya dengan uji normalitas (Saphiro-Wilk) dan uji homogenitas (Levene test). Kemudian data dianalisis menggunakan Paired $t$-test dengan $\alpha=0,05$, untuk menguji pengaruh tiap variabelnya dan Independent sample t-test dengan $\alpha=0,05$, untuk menganalisa apakah terdapat pengaruh pemberian jus buah naga merah terhadap jumlah leukosit. Data yang diperoleh selanjutnya diolah dengan uji statistik

\section{HASIL DAN PEMBAHASAN}

\section{Hasil}

Hasil uji normalitas jumlah leukosit pretest dan posttest pada ke dua kelompok dengan menggunakan uji Saphiro-Wilk menunjukkan bahwa data leukosit berdistribusi normal ( $>0,05)$. Ratarata jumlah leukosit pada pretest dan posttest masing-masing pada kedua kelompok yaitu kelompok P1, kelompok yang melakukan latihan fisik intensitas berat tanpa diberi jus buah naga merah dan kelompok P2, kelompok yang latihan fisik intensitas berat serta diberi jus buah naga merah, dapat dilanjutkan dengan Paired t-test, hasil nya tercantum pada Tabel 1, dimana P1 adalah kelompok control, dan P2 adalah kelompok diberi jus buah naga merah.

Tabel 1. Hasil Uji t Berpasangan jumlah leukosit

\begin{tabular}{cccccc}
\hline & \multicolumn{3}{c}{ Pre test } & \multicolumn{3}{c}{ Post test } & Uji t \\
\cline { 2 - 5 } & mean & $\pm \mathrm{sd}$ & mean & $\pm \mathrm{sd}$ & $\mathrm{p}$ \\
\hline P1 & 6184 & $\pm 0,928$ & 10840 & $\pm 2,124$ & 0,009 \\
P2 & 6210 & $\pm 0,984$ & 7726 & $\pm 1,366$ & 0,021 \\
\hline
\end{tabular}

Pada Tabel 1, diketahui rata-rata jumlah leukosit pretest pada kelompok latihan fisik intensitas berat tanpa diberi jus buah naga merah (P1) adalah $6184 \mathrm{sel} / \mathrm{mm}^{3}$ dan pada posttest adalah 10840 $\mathrm{sel} / \mathrm{mm}^{3}$. Hasil ini menunjukkan bahwa ada pengaruh latihan fisik intensitas berat terhadap peningkatan jumlah leukosit, dengan $p$ value $=0,009 ; \mathrm{p}<0,05$. Rata-rata jumlah leukosit pretest pada kelompok melakukan latihan fisik intensitas berat serta diberi jus buah naga merah adalah $6210 \mathrm{sel} / \mathrm{mm}^{3}$ dan pada 
posttest adalah $7726 \mathrm{sel} / \mathrm{mm}^{3}$. Hasil ini menunjukkan bahwa ada pengaruh latihan fisik intensitas berat serta diberi jus buah naga merah terhadap peningkatan jumlah leukosit, dengan $p$ value $=0,021 ; \mathrm{p}<0,05$.

Untuk mengetahui pengaruh pemberian buah naga merah setelah latihan fisik intensitas berat terhadap jumlah leukosit maka dilanjutkan dengan uji Independent T-Test, hasilnya seperti pada Gambar 1, dimana P1 adalah kelompok control, dan P2 adalah kelompok diberi jus buah naga merah.

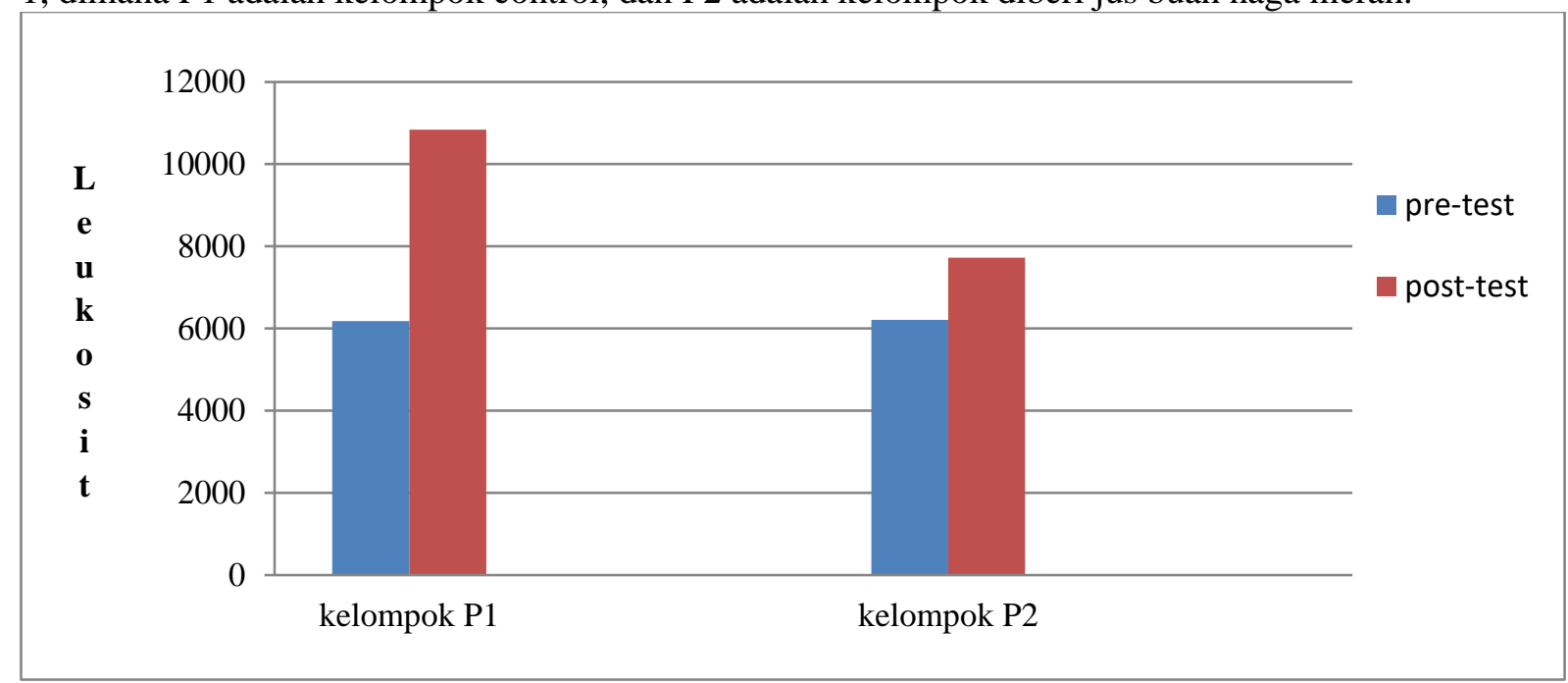

Gambar 1. Perubahan jumlah leukosit (sel/ $\left.\mathrm{mm}^{3}\right)$

Gambar 1, menunjukkan bahwa pada kelompok P1 dan kelompok P2 sama-sama terjadi peningkatan terhadap jumlah leukosit setelah latihan fisik intensitas berat. Akan tetapi peningkatan jumlah leukosit pada kelompok latihan fisik intensitas berat yang diberi jus buah naga merah lebih rendah dibandingkan jumlah leukosit pada kelompok latihan fisik intensitas berat tanpa jus buah naga merah. Dengan demikian dapat dinyatakan bahwa pemberian jus buah naga merah dapat mengurangi jumlah leukosit setelah latihan fisik intensitas berat lebih rendah dibanding jumlah leukosit yang tidak mendapat jus buah naga merah.

\section{Pembahasan}

Penelitian ini bertujuan untuk mengetahui pengaruh pemberian jus buah naga merah terhadap jumlah leukosit setelah melakukan latihan fisik intensitas berat pada subjek yang diberi jus buah naga merah dengan yang tidak diberi jus buah naga merah. Berdasarkan hasil penelitian diperoleh bahwa latihan fisik intensitas berat, dapat menyebabkan peningkatan jumlah leukosit pada ke dua kelompok. Akan tetapi jumlah leukosit pada kelompok yang mendapatkan jus buah naga merah. lebih rendah dibandingkan pada kelompok yang tidak mendapatkan buah naga merah. Adapun yang dapat membantu menurunnya jumlah leukosit yaitu dengan diberinya jus buah naga merah yang mangandung flavonoid dan polifenol yang mempunyai potensi sebagai antioksidan. Dengan diberikannya buah naga yang mengandung antioksidan maka radikal bebas yang dihasilkan selama latihan fisik intensitas berat dapat di seimbangkan.

Pada kelompok yang diberi jus buah naga merah diperoleh jumlah leukosit lebih rendah dibanding kelompok yang tidak diberi jus buah naga merah, hal ini karena berlangsungnya adaptasi sistem pertahanan antioksidan sebagai respon terhadap asupan nutrisi yang terkandung dalam jus buah naga merah seperti flavonoid dan polifenol yang memiliki kemampuan sebagai antioksidan (Niah \& Helda, 2017).

Radikal bebas dapat dihasilkan pada keadaan fungsi seluler normal dan merupakan bagian dari proses fisiologis alami semua makhluk hidup (Jiao et al., 2017). Radikal bebas dapat bertindak sebagai senyawa yang bermanfaat dan juga sebaliknya dapat merusak, karena mereka dapat menguntungkan atau berbahaya bagi tubuh (Pham-Huy et al., 2008). Ketika radikal bebas berlebih sehingga tidak dapat secara bertahap diproses atau kurangnya ketersediaan perlindungan tubuh antioksidan alami, akumulasi radikal bebas dalam tubuh menyebabkan kerusakan oksidatif yang dikenal sebagai stres oksidatif (Simioni et al., 2018). 
Adanya peningkatan jumlah leukosit pada kelompok yang tidak diberi jus buah naga merah, karena selama latihan fisik intensitas berat dihasilkan radikal bebas yang mengoksidasi membran sel yang dapat merangsang sel leukosit. Peningkatan jumlah leukosit setelah melakukan latihan fisik intensitas berat sesuai dengan hasil penelitian yang menyatakan bahwa latihan fisik intensitas berat berpotensi merangsang peningkatan produksi radikal bebas yang melebihi kemampuan sistem pertahanan antioksidan seluler sehingga menyebabkan terjadnya stress oksidatif (Thirumalai et al., 2011).

Hasil penelitian ini sesuai dengan penelitian oleh (Sinaga et al., 2018) yang menyatakan bahwa pemberian jus buah jambu biji merah pada atlet selama menjalani program latihan dapat mengurangi peningkatan jumlah leukosit pada saat melakukan aktifitas fisik maksimal. Hasil penelitian ini juga sejalan dengan penelitian terdahulu yang menyatakan bahwa setelah aktifitas fisik berat yang dilakukan selama 15 menit serta aktifitas fisik berat sampai 60 menit terjadi peningkatan jumlah leukosit diatas normal (Peake \& Suzuki, 2004). Pada keadaan normal atau fisiologis, sekitar 5\% dari konsumsi oksigen akan membentuk radikal bebas, namun masih dapat dinetralisir oleh antioksidan yang ada di dalam tubuh (Cooper, 2000). Akan tetapi pada keadaan latihan fisik intensitas berat dan melelahkan kecepatan pembentukan radikal bebas dapat meningkat melebihi 5\%. Pada keadaan ini maka kemampuan kapasitas sistem pertahanan antioksidan tidak mencukupi untuk menetralkan radikal bebas atau dengan kata lain terjadi ketidakseimbangan antara antioksidan endogen dengan radikal bebas maka dapat menyebabkan stres oksidatif dan merangsang aktifitas sel leukosit (Cooper, 2000).

Peningkatan jumlah leukosit setelah latihan fisik berat disebabkan karena respon inflamasi akut dan cedera jaringan akibat stress oksidatif. Kondisi stres oksidatif mengakibatkan leukosit menembus dinding endotel pembuluh darah masuk ke jaringan yang mengalami kerusakan akibat stress oksidatif dan memfagositosis jaringan yang rusak sehingga terjadi peningkatan jumlah leukosit akibat kerusakan oksidatif (Nielsen et al., 2004; van Helvoort et al., 2007). Aktifitas seluler yang terjadi adalah pergerakan leukosit menembus dinding pembuluh darah (diapedesis) sehingga leukosit migrasi ke dalam sirkulasi pembuluh darah. Leukosit mengeluarkan enzim hidrolitik yang membantu menembus dinding pembuluh darah (diapedesis) karena daya kemotaksis (Sherwood, 2015).

Adanya jumlah leukosit yang meningkat setelah latihan fisik intensitas berat hal ini sejalan dengan penelitian yang dilakukan oleh (Irianti, 2008; Risøy et al., 2003; Simonson \& Jackson, 2004; Sodique et al., 2000); dan Tossige-Gomes et al. (2014). Hasil penelitian terdahulu menyatakan bahwa aktifitas fisik aerobik dan aktifitas fisik anaerobik dapat meningkatkan jumlah leukosit (Atan \& Alacam, 2015; Harahap \& Pahutar, 2018). Beberapa penelitian telah meneliti efek dari olahraga akut pada leukosit pada orang tua. Misalnya, Penelitian oleh (Ludlow et al., 2008) pada sampel 69 orang yang berusia 50-70 tahun menemukan bahwa aktivitas fisik moderat (50-70\% VO2max) terhadap jumlah leukosit dapat meningkat dibandingkan dengan kelompok yang melakukan aktifitas fisik intensitas rendah.

Leukosit (granulosit dan monosit serta sedikit limfosit) diproduksi di sumsum tulang dan berperan aktif dalam sistem pertahanan tubuh, serta sebagian lagi diproduksi di jaringan limfe (Limfosit sel-sel plasma). Dari sumsum tulang, sel - sel leukosit ini diangkut dalam sirkulasi menuju seluruh tubuh untuk digunakan (Guyton \& Hall, 2006). Leukosit dan jenis-jenis leukosit berfungsi sebagai benteng dari invasi oleh patogen (mikroorganisme penyebab penyakit misalnya bakteri dan virus) melalui proses fagositosis; mengidentifikasikan dan menghancurkan sel-sel kanker yang muncul di dalam tubuh dan berfungsi sebagai petugas pembersih yang membersihkan sampah tubuh dengan memfagositosis debris yang berasal dari sel yang mati atau cedera. Yang terakhir penting dalam penyembuhan luka dan perbaikan jaringan. Untuk melaksanakan fungsinya, leukosit terutama menggunakan strategi " search and fight" yaitu sel-sel tersebut pergi ke tempat invasi atau jaringan yang rusak (Sherwood, 2015).

Leukosit dapat melakukan gerakan amuboid dan melalui proses diapedesis leukosit dapat meninggalkan kapiler dengan menembus dinding pembuluh darah yang tersusun dari sel-sel endotel dan menembus kedalam jaringan penyambung. Leukosit ditransport secara khusus ke jaringan yang mengalami infeksi dan mengalami peradangan seperti latihan fisik intensitas berat (Guyton \& Hall, 2006).

Buah naga merah diketahui mengandung senyawa flavonoid dan polifenol, dimana senyawa ini mempunyai aktivitas antioksidan untuk mengikat radikal bebas dalam sistem biologis (Mahattanatawee et al., 2006). Flavonoid yang terkandung dalam buah naga merah berperan sebagai antioksidan karena dapat menetralisir radikal bebas dengan cara melepaskan atom hidrogen dari gugus hidroksilnya. Pemberian atom hidrogen ini menyebabkan radikal bebas menjadi stabil sehingga tidak merusak lipid, 
protein, dan DNA (Sundaryono, 2011). Dari hasil penelitian sebelumnya diketahui bahwa senyawa flavonoid mampu menurunkan jumlah leukosit pada tikus yang diinduksi benzo[ $\alpha]$ piren $(\mathrm{BaP})$ (Sundaryono, 2011).

Potensi buah naga merah sebagai antioksidan juga didukung oleh penelitian (Harahap et al., 2019) yang menyatakan bahwa buah naga merah merupakan antioksidan yang baik bermanfaat menurunkan stress oksidatif akibat latihan fisik intensitas berat karena dapat mencegah peningkatan malondialdehyde dan alkaline phosphatase pada tikus dengan kondisi stress oksidatif. Sehingga hal ini dapat menerangkan bahwa respon jumlah leukosit yang dapat mneingkat saat lathan fisik intensitas berat dapat dikurangi dengan mengkonsumsi buah naga mearh.

\section{SIMPULAN}

Kesimpulan penelitian ini menunjukkan bahwa peningkatan jumlah leukosit pada kelompok yang mendapat jus buah naga merah lebih rendah dibandingkan kelompok yang tidak mendapat jus buah naga merah setelah latihan fisik intensitas berat. Dengan demikian dapat dinyatakan bahwa pemberian jus buah naga merah dapat mengurangi peningkatan jumlah leukosit setelah melakukan latihan fisik intensitas berat. Sebagai saran untuk penelitian seperti ini selanjutnya menggunakan design penelitian cross over.

\section{DAFTAR PUSTAKA}

Arifin, H., Nofiza, W., \& Elisma, E. (2012). Pengaruh pemberian jus buah naga hylocereus undatus (haw.) Britt \& Rose terhadap jumlah hemoglobin, eritrosit dan hematokrit pada mencit putih betina. Jurnal Sains Dan Teknologi Farmasi, 17(2), 118-125.

Atan, T., \& Alacam, H. (2015). The effects of acute aerobic and anaerobic exercise on blood parameters. The Anthropologist, 19(1), 87-93. https://doi.org/10.1080/09720073.2015.11891642

Bhatti, R., \& Shaikh, D. M. (2007). The effect of exercise on blood parameters. Pakistan Journal of Physiology, 3(2). http://pjp.pps.org.pk/index.php/PJP/article/view/651

Braakhuis, A. J., \& Hopkins, W. G. (2015). Impact of dietary antioxidants on sport performance: A review. Sports Medicine, 45(7), 939-955. https://doi.org/10.1007/s40279-015-0323-x

Cooper, K. H. (2000). Antioxidant revolution. Thomas Nelson Publishers.

Dékány, M., Nemeskéri, V., Györe, I., Ékes, E., Gógl, Á., Szőts, G., Petrekanits, M., Taylor, A. W., Berkes, I., \& Pucsok, J. (2008). Physical performance and antioxidant effects in triathletes. Biology of Sport, 25(2), 101-114.

Ganong, W. F. (2010). Review of medical physiology (23rd ed.). Mcgraw-hill.

Gleeson, M., \& Robson-Ansley, P. (2006). Immune response to intensified training and overtraining. In M. Gleeson (Ed.), Immune function in sport and exercise (pp. 115-138). Churchill Livingstone Elsevier.

Gomez-Cabrera, M.-C., Domenech, E., \& Viña, J. (2008). Moderate exercise is an antioxidant: Upregulation of antioxidant genes by training. Free Radical Biology and Medicine, 44(2), 126131. https://doi.org/10.1016/j.freeradbiomed.2007.02.001

Guyton, A. C., \& Hall, J. E. (2006). Textbook of medical physiology (11th ed.). Elsevier Inc.

Harahap, N. S., \& Pahutar, U. P. (2018). Pengaruh aktifitas fisik aerobik dan anaerobik terhadap jumlah leukosit pada Mahasiswa Ilmu Keolahragaan Universitas Negeri Medan. Sains Olahraga : Jurnal Ilmiah Ilmu Keolahragaan, 1(2), 33. https://doi.org/10.24114/so.v1i2.7785

Harahap, N. S., Simatupang, N., \& . S. (2019). Potential of the red dragon fruit (Hylocereus polyrhizus) as an antioxidant in strenuous exercise. Biotechnology(Faisalabad), 19(1), 18-22. https://doi.org/10.3923/biotech.2020.18.22

Hazar, S., \& Y1lmaz, G. (2008). Acute effect of submaximal treadmill exercise on immune system. Proceeding of the 10th International Sports Science Congress; 2008 October; Bolu, 23-25.

Irianti, E. (2008). Pengaruh aktifitas fisik sedang terhadap hitung leukosit dan hitung jenis sel leukosit pada orang tidak terlatih. USU e-Repository.

Jiao, Y., Wang, Y., Guo, S., \& Wang, G. (2017). Glutathione peroxidases as oncotargets. Oncotarget. 
https://doi.org/10.18632/oncotarget.20278

Kawamura, T., \& Muraoka, I. (2018). Exercise-induced oxidative stress and the effects of antioxidant intake from a physiological viewpoint. Antioxidants, 7(9), 119. https://doi.org/10.3390/antiox7090119

Khotimah, K., Anantanyu, S., Wiboworini, B., \& Hanim, D. (2018). Pengaruh jus buah naga merah dan senam terhadap kadar HDL lansia. Jurnal Kesehatan Kusuma Husada, 9(2), 213-219. https://doi.org/10.34035/jk.v9i2.282

Ludlow, A. T., Zimmerman, J. B., Witkowski, S., Hearn, J. W., Hatfield, B. D., \& Roth, S. M. (2008). Relationship between physical activity level, telomere length, and telomerase activity. Medicine \& Science in Sports \& Exercise, 40(10), 1764-1771. https://doi.org/10.1249/MSS.0b013e31817c92aa

Mahattanatawee, K., Manthey, J. A., Luzio, G., Talcott, S. T., Goodner, K., \& Baldwin, E. A. (2006). Total antioxidant activity and fiber content of select florida-grown tropical fruits. Journal of Agricultural and Food Chemistry, 54(19), 7355-7363. https://doi.org/10.1021/jf060566s

Marciniak, A., Brzeszczyńska, J., Gwoździński, K., \& Jegier, A. (2009). Antioxidant capacity and physical exercise. Biology of Sport, 26(3), 197-213. https://doi.org/10.5604/20831862.894649

Marius-Daniel, R., Stelian, S., \& Dragomir, C. (2010). The effect of acute physical exercise on the antioxidant status of the skeletal and cardiac muscle in the Wistar rat. Romanian Biotechnol Lett, 15(3), 56-61. https://e-repository.org/rbl/vol.15/iss.3.s/10.pdf

Mastorakos, G., Pavlatou, M., Diamanti-Kandarakis, E., \& Chrousos, G. P. (2005). Exercise and the stress system. Hormones, 4(2), 73-89.

Minh, N. P. (2014). Various factory influencing to red dragon fruit (Hylocereus Polyrhizus) wine fermentation. Internataional Journal of Multidisciplinary Research and Development, 1(5), 9498.

Natale, V. M., Brenner, I. K., Moldoveanu, A. I., Vasiliou, P., Shek, P., \& Shephard, R. J. (2003). Effects of three different types of exercise on blood leukocyte count during and following exercise. Sao Paulo Medical Journal, 121(1), 09-14. https://doi.org/10.1590/S151631802003000100003

Niah, R., \& Helda, H. (2017). Aktivitas antioksidan ekstrak etanol kulit buah naga merah Daerah Pelaihari, Kalimantan Selatan dengan metode DPPH (2, 2-difenil-1-pikrilhidrazil). Jurnal Pharmascience, 3(2). https://doi.org/10.20527/jps.v3i2.5736

Nielsen, H. G., Hagberg, I. A., \& Lyberg, T. (2004). Marathon running leads to partial exhaustion of ROS-generating capacity in leukocytes. Medicine \& Science in Sports \& Exercise, 36(1), 68-73. https://doi.org/10.1249/01.MSS.0000106168.12113.95

Patlar, S. (2010). Effects of acute and 4-week submaximal exercise on leukocyte and leukocyte subgroups. Isokinetics and Exercise Science, 18(3), 145-148. https://doi.org/10.3233/IES-20100373

Peake, J., \& Suzuki, K. (2004). Neutrophil activation, antioxidant supplements and exercise-induced oxidative stress. Exercise Immunology Review, 10(1), 129-141.

Pham-Huy, L. A., He, H., \& Pham-Huy, C. (2008). Free radicals, antioxidants in disease and health. International Journal of Biomedical Science, 4(2), 89-96.

Putra, K. P., Al Ardha, M. A., Kinasih, A., \& Aji, R. S. (2017). Korelasi perubahan nilai VO2max, eritrosit, hemoglobin dan hematokrit setelah latihan high intensity interval training. Jurnal Keolahragaan, 5(2), 161. https://doi.org/10.21831/jk.v5i2.14875

Rao, P. S., Kalva, S., Yerramilli, A., \& Mamidi, S. (2011). Free radicals and tissue damage: Role of antioxidants. Free Radicals and Antioxidants, 1(4), 2-7. https://doi.org/10.5530/ax.2011.4.2

Risøy, B. A., Raastad, T., Hallén, J., Lappegård, K. T., Bæverfjord, K., Kravdal, A., Siebke, E. M., \& Benestad, H. B. (2003). Delayed leukocytosis after hard strength and endurance exercise: Aspects of regulatory mechanisms. BMC Physiology, 3(14). https://doi.org/10.1186/1472-67933-14

Sherwood, L. (2015). Fisiologi manusia: Dari sel ke sistem (D. R. Herman Octavius Ong, Albertus 
Agung Mahode (ed.); 8th ed.). EGC.

Simioni, C., Zauli, G., Martelli, A. M., Vitale, M., Sacchetti, G., Gonelli, A., \& Neri, L. M. (2018). Oxidative stress: role of physical exercise and antioxidant nutraceuticals in adulthood and aging. Oncotarget, 9(24), 17181-17198. https://doi.org/10.18632/oncotarget.24729

Simonson, S. R., \& Jackson, C. G. R. (2004). Leukocytosis occurs in response to resistance exercise in men. The Journal of Strength and Conditioning Research, 18(2), 266. https://doi.org/10.1519/R12572.1

Sinaga, F. A., Risfandi, M., Ginting, M., \& Fitri, K. (2018). Pengaruh pemberian jus jambu biji merah terhadap jumlah leukosit pada aktifitas fisik maksimal. Sains Olahraga : Jurnal Ilmiah Ilmu Keolahragaan, 1(2), 51. https://doi.org/10.24114/so.v1i2.7787

Sodique, N. O., Enyikwola, O., \& Ekanem, A. U. (2000). Exercise-induced leucocytosis in some healthy adult Nigerians. African Journal of Biomedical Research, 3(2), 85-88. https://www.ajol.info/index.php/ajbr/article/view/140712

Stintzing, F. C., Schieber, A., \& Carle, R. (2002). Betacyanins in fruits from red-purple pitaya, Hylocereus polyrhizus (Weber) Britton \&amp; Rose. Food Chemistry, 77(1), 101-106. https://doi.org/10.1016/S0308-8146(01)00374-0

Sundaryono, A. (2011). Uji aktivitas senyawa flavonoid total dari Gynura segetum (lour) terhadap peningkatan eritrosit dan penurunan leukosit pada mencit (Mus musculus). EXACTA, 9(2), 8-16.

Thirumalai, T., Therasa, S. V., Elumalai, E., \& David, E. (2011). Intense and exhaustive exercise induce oxidative stress in skeletal muscle. Asian Pacific Journal of Tropical Disease, 1(1), 6366. https://doi.org/10.1016/S2222-1808(11)60016-9

Tossige-Gomes, R., Ottone, V. O., Oliveira, P. N., Viana, D. J. S., Araujo, T. L., Gripp, F. J., \& Rocha-Vieira, E. (2014). Leukocytosis, muscle damage and increased lymphocyte proliferative response after an adventure sprint race. Brazilian Journal of Medical and Biological Research, 47(6), 492-498. https://doi.org/10.1590/1414-431X20143187

Urso, M. L., \& Clarkson, P. M. (2003). Oxidative stress, exercise, and antioxidant supplementation. Toxicology, 189(1-2), 41-54. https://doi.org/10.1016/S0300-483X(03)00151-3

Valizadeh, A., Hossini, M. K., \& Heris, M. S. (2011). Immune response to changes in training intensity and duration in male athletes. Annals of Biological Research, 2(6), 662-667.

van Helvoort, H. A. C., Heijdra, Y. F., de Boer, R. C. C., Swinkels, A., Thijs, H. M. H., \& Dekhuijzen, P. N. R. (2007). Six-minute walking-induced systemic inflammation and oxidative stress in muscle-wasted copd patients. Chest, 131(2), 439-445. https://doi.org/10.1378/chest.06-1655

Yavari, A., Javadi, M., Mirmiran, P., \& Bahadoran, Z. (2015). Exercise-induced oxidative stress and dietary antoxidative. Asian Journal of Sports Medicine, 6(1). https://doi.org/10.5812/asjsm.24898 